\title{
Article
}

\section{Tree Growth Response to Low-Intensity Prescribed Burning in Pinus nigra Stands: Effects of Burn Season and Fire Severity}

\author{
Juncal Espinosa ${ }^{1, *}$, Dario Martin-Benito ${ }^{2}$, Óscar Rodríguez de Rivera ${ }^{3} \mathbb{D}$, Carmen Hernando ${ }^{1,4}$, \\ Mercedes Guijarro ${ }^{1,4}$ (D) and Javier Madrigal 1,4,5
}

1 Forest Research Center CSIC-INIA, Forest Fire Laboratory, Carretera de La Coruña, 28040 Madrid, Spain; lara@inia.es (C.H.); guijarro@inia.es (M.G.); incendio@inia.es (J.M.)

2 Forest Research Center CSIC-INIA, Laboratory of Functional Ecology of Forest Tree Species, Carretera de La Coruña, 28040 Madrid, Spain; dmartin@inia.es

3 School of Mathematics, Statistics and Actuarial Science, University of Kent, Canterbury CT2 7NZ, UK; o.ortega@kent.ac.uk

4 iuFOR, University Institute for Sustainable Forest Management, UVa-INIA, 34004 Palencia, Spain

5 School of Forest Engineering and Natural Resources, University Polytechnic of Madrid, 28040 Madrid, Spain

* Correspondence: espinosa.juncal@inia.es; Tel.: +34-91-347-6880

check for updates

Citation: Espinosa, J.; Martin-Benito, D.; Rodríguez de Rivera, Ó.;

Hernando, C.; Guijarro, M.; Madrigal,

J. Tree Growth Response to

Low-Intensity Prescribed Burning in Pinus nigra Stands: Effects of Burn Season and Fire Severity. Appl. Sci. 2021, 11, 7462. https://doi.org/ 10.3390/app11167462

Academic Editor: Pietro Picuno

Received: 30 June 2021

Accepted: 10 August 2021

Published: 13 August 2021

Publisher's Note: MDPI stays neutral with regard to jurisdictional claims in published maps and institutional affiliations.

Copyright: (c) 2021 by the authors. Licensee MDPI, Basel, Switzerland. This article is an open access article distributed under the terms and conditions of the Creative Commons Attribution (CC BY) license (https:// creativecommons.org/licenses/by/ $4.0 /)$.

\begin{abstract}
The study of the short-term post-burn tree growth in a mixed stand of Pinus nigra and Pinus pinaster and in a pure stand of P. nigra in the Cuenca Mountains (Spain) will enable us to determine the disturbance of prescribed burning conducted in two seasons. Dendrochronological methods and mixed modelling were used to investigate whether tree growth responses are influenced by stand and tree characteristics, fire season and fire severity variables. The findings revealed that prescribed burning scarcely affected tree growth. The type of stand (mixed or pure) was not critical for tree growth. The individual tree characteristics were significant factors in all the scenarios studied. The inclusion of some fire severity variables for the first time in tree growth models showed that the maximum scorch height determined a main part of the variability of tree growth. The time during which the temperature was above $60^{\circ} \mathrm{C}$ in the cambium region and temperature was above $300{ }^{\circ} \mathrm{C}$ in the bark surface were only significant factors after spring burnings. The litterfall one year after the prescribed burning was not a significant factor in any of the models. Overall, the findings confirm the characteristic resistance of $P$. nigra to surface fires and favor the potential application of prescribed burning programs for this species in the Mediterranean Basin.
\end{abstract}

Keywords: forest ecology; disturbance; fire ecology; forest management; forest fires

\section{Introduction}

Large wildfires are a common occurrence in Mediterranean forests. However, within the framework of global climate change, interactions between climate and fire may accentuate the effects, or at least, alter the stress on ecosystems [1,2]. Prescribed burning (PB) is an active forest management tool that can reduce the intensity and severity of forest fires, when it is strategically applied in both time and space [3-5]. Beyond fire prevention, PB may also be beneficial for the vitality of ecosystems, recovering the distribution of the most balanced vegetation layers and occasionally improving biodiversity [6-8]. Nonetheless, PB activity in southern Europe remains local in scope and the area treated is quite modest [9], although in recent years an effort is being made to include PB in forest management plans. In addition, forest managers often do not have access to accurate and research-supported information about the potential effects of prescribed burning on different forest ecosystems. This may lead to the application of unsuitable prescribed fire regimes that can cause significant damage or mortality to tree species and indirectly alter biotic and abiotic processes [10].

The responses of plant function to fire activity are complex and can vary widely [11]. Thus, fire-surviving trees can be compromised in their physiological functionality, show 
reduced growth and be more likely to succumb to delayed death (e.g., [12-14]). Conversely, the injured trees may also benefit in the short- and mid-term from reduced competition [15-17]. However, few studies have modelled individual growth responses as a function of tree and stand characteristics including fire intensity (e.g., residence time above a lethal temperature) and severity variables (e.g., scorch height or total amount of litterfall after fire treatment) [16,17]. In the Cuenca Mountains (Iberian System), prescribed burning is usually carried out in the early season (spring) and late season (early autumn). Although the burn season can be easily controlled in PB treatments, little is known about how the burn season affects post-fire tree growth [17]. Some studies have shown that early season burning at the beginning of the annual growth period is more likely to cause heat damage $[18,19]$. Conversely, late season burning is likely to be of greater intensity because the fuels are drier [20], which may exacerbate tree mortality [21].

Other specific stand and individual tree characteristics are widely recognized sources of variability in relation to tree growth (e.g., density, age, phenotypic plasticity, genetic variability and interactions with site factors) [22-24] and should be considered in tree growth studies. The present study involved a mixed stand of Pinus nigra Arn. ssp. salzmannii (Spanish black pine) and Pinus pinaster Ait. (maritime pine) and a pure stand of P. nigra. The Cuenca Mountains are representative of areas where the P. nigra-P. pinaster ecotone generates stable stands with ecosystem services of high ecological value. This species richness has previously been associated with stand-level stability in the face of disturbance [25-27], which may be explained by the aggregate properties of species. Thus, the exploration of the resilience of pure and mixed stands to perturbations such as prescribed burning is essential to establish recommendations for management and fire prevention strategies in this area. In addition, these species have been recognized to be adapted to surface fires with the following different characteristics: thick bark, high crown base height, self-pruning strategy and open structure in the case of Pinus nigra (e.g., [28-30]) or serotine cones and thick bark, large buds shielded by scales and by long needles in the case of Pinus pinaster (e.g., $[28,31,32])$.

Moreover, in order to achieve the management objectives of $\mathrm{PB}$, the burn window must be applied to reach the desired outcomes regarding fire behavior and the associated impacts. The maximum scorch height and time of exposure to a critical temperature of $60{ }^{\circ} \mathrm{C}$ in the cambium area [33] were used in the present study as proxies for damage to the cambium and severity of burning at the tree level $[34,35]$. As far as we are aware, this is the first time that these variables have been included together in tree growth models. The inclusion of these variables may improve the results in relation to predicting the effect of burn intensity and duration of high temperatures on living tissues below the bark (damage or severity of fire in cambium and phloem), which have been considered the most important stress factors affecting trees [36]. In addition, the time of exposure to a critical temperature of $60{ }^{\circ} \mathrm{C}$ in the cambium area has been proposed for improving growth models [16]. At the same time, tree growth is closely related to the amount of leaf-fall [37]. Tree growth often declines after fire [38] because burning affects photosynthesis by increasing leaf-fall and, thus, reducing the photosynthetic efficiency of the remaining leaves [39] and also by altering transpiration patterns and water use efficiency [40]. However, some positive effects on tree growth after PB have been described in relation to crown damage [41]. The variables commonly used to indicate crown injury criterion include the level of crown scorched and the crown scorch height (e.g., [42]). However, nothing is known about the effects of an increase in litterfall biomass after PB on tree growth. In a recent study in the same experimental plots, we found that even low-intensity PB (with low values of crown scorched and crown scorch height) can increase the litterfall relative to that in unburned plots in the short-term [43]. Thus, litterfall biomass after PB was included for the first time in the model as a predictor of burn severity at the stand level, relating crown damage and tree growth.

In this study, we examined how PB conducted as a surface fuel hazard reduction treatment in two different seasons (spring and autumn) affected the short-term growth of two 
types of Pinus nigra stands (mixed and pure). In the context of a more comprehensive study of the introduction of prescribed fire as a management tool in Spanish forest stands [44], we hypothesize that low-intensity PB will not have an important effect on tree growth in the short-term and that the fire effects will be more notable in pure stands owing to the greater resilience of mixed stands to perturbations [25,43,45].

The study aims were as follows: (i) to ascertain any consistent variations in the post-PB growth of P. nigra; (ii) to examine the potential effects of burning season; (iii) to analyze the interactions between species mixture and burning on tree growth; and (iv) to explore the effect of fire severity during burning at tree and stand level.

\section{Materials and Methods}

\subsection{Study Sites}

Two areas in the Cuenca Mountains (Iberian System) separated by a straight-line distance of $14 \mathrm{~km}$ were selected for the study (Figure 1): a mixed stand of Pinus nigra $(89 \pm 11 \%)$ and Pinus pinaster $(11 \pm 11 \%)$ in El Pozuelo and a pure stand of P. nigra in Beteta. The main characteristics of both stands are shown in Table 1 .

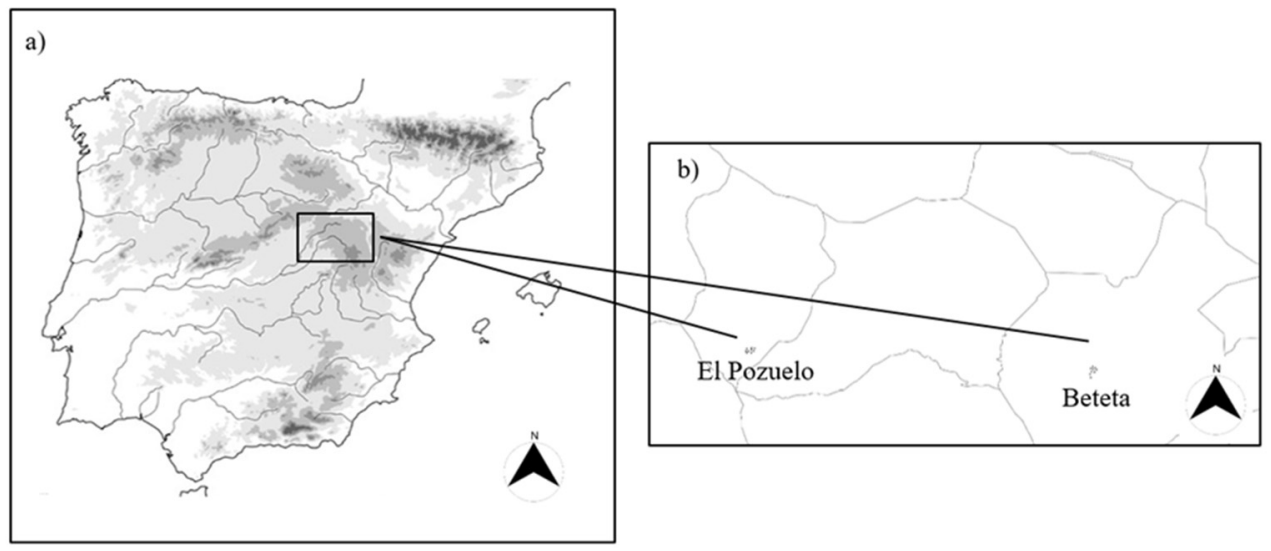

Figure 1. Locations of the study plots in (a) the Iberian Peninsula $(1: 1,250,000)$; (b) El Pozuelo (mixed P. nigra-P. pinaster stand) and Beteta (pure P. nigra stand) (1:50,000).

Table 1. Main characteristics of mixed and pure stands (mean and standard deviation) [46].

\begin{tabular}{|c|c|c|}
\hline- & Mixed Stand & Pure Stand \\
\hline Coordinates-Longitude & $40^{\circ} 33^{\prime} 36^{\prime \prime} \mathrm{N}$ & $40^{\circ} 33^{\prime} 06^{\prime \prime} \mathrm{N}$ \\
\hline Coordinates-Latitude & $002^{\circ} 15^{\prime} 56^{\prime \prime} \mathrm{W}$ & $002^{\circ} 06^{\prime} 32^{\prime \prime} \mathrm{W}$ \\
\hline Main species & $\begin{array}{c}\text { Pinus nigra }(89 \pm 11 \%) \\
\text { Pinus pinaster }(11 \pm 11 \%)\end{array}$ & Pinus nigra $(100 \%)$ \\
\hline pH of topsoil ${ }^{1}$ & 7.3 (clay texture) & 6.9 (loamy-sand texture) \\
\hline Elevation & $1016 \pm 5 \mathrm{~m}$ asl & $1232 \pm 7 \mathrm{~m}$ asl \\
\hline Slope & $3-8 \%$ & $3-10 \%$ \\
\hline Stand density & $627 \pm 238$ trees ha $^{-1}$ & $1286 \pm 339$ trees $\mathrm{ha}^{-1}$ \\
\hline Stand basal area & $25.4 \pm 9.7 \mathrm{~m}^{2} \mathrm{ha}^{-1}$ & $36.6 \pm 10.7 \mathrm{~m}^{2} \mathrm{ha}^{-1}$ \\
\hline Dominant tree height & $18.6 \pm 0.8 \mathrm{~m}$ & $17.0 \pm 1.6 \mathrm{~m}$ \\
\hline Tree height & $12.2 \pm 2.0 \mathrm{~m}$ & $13.2 \pm 2.7 \mathrm{~m}$ \\
\hline Diameter at breast height (DBH) & $19.8 \pm 2.6 \mathrm{~cm}$ & $18.8 \pm 4.1 \mathrm{~cm}$ \\
\hline Bark thickness & $1.7 \pm 0.3 \mathrm{~cm}$ & $1.7 \pm 0.4 \mathrm{~cm}$ \\
\hline
\end{tabular}

${ }^{1}$ Data from [45].

According to the data recorded at the Cañizares weather station (940 m asl) and provided by the State Meteorological Agency of the Spanish Government [47], the mean annual temperature was $11.3^{\circ} \mathrm{C}$ and the average precipitation was $747 \mathrm{~mm}$ in the last 46 years. 


\subsection{Experimental Design}

Within the study site, a total of 18 plots $(n=9$ in the mixed stand and $n=9$ in the pure stand), each measuring $50 \mathrm{~m} \times 50 \mathrm{~m}$, were selected following a completely randomized plot design in order to avoid pseudo replicates. For data collection, subplots of $30 \times 30 \mathrm{~m}$ were established in order to prevent the edge effect. Three treatments (no burning, spring burning and autumn burning) were applied to each type of stand, with 3 replicates per treatment (for further details, see $[35,43,48]$ ). In order to obtain data on post-fire growth and temperatures during the burns, 15 P. nigra trees in each plot were selected for study $(n=135$ in the mixed stand and $n=135$ in the pure stand). The trees were chosen to represent all of the diametric classes present in each particular plot.

\subsection{Burning and Fire Severity at Tree Level}

Spring burning was conducted on 15 May 2016, before the main growth season; while autumn burning was carried out on 15 November 2016, after the main growth season. The strip ignition technique was applied at a distance of 1-2 $\mathrm{m}$ downhill, facing a headwind. This technique is the most widely used in the study area to produce low-medium-intensity fire [49]. During the burning, the temperature (T) and relative humidity ( $\mathrm{RH})$ (Geonica; STH-5031) and wind speed (WS) (Casella; 178031C-3) were recorded every $10 \mathrm{~min}$ at a meteorological station located adjacent to the study plots (about $100 \mathrm{~m}$ from the plot). In order to estimate burn severity at tree level during the burning, the temperature in the cambial region (inner bark) and in the bark surface of the 15 selected P. nigra trees in each plot was monitored at a height of $0.6 \mathrm{~m}$ [50] with type K 1-millimeter-diameter inconel-sheathed thermocouples (response time, $0.3 \mathrm{~s}$ ). The thermocouples were connected to data loggers (DT-USB TCDirect ${ }^{\circledR}$ ), which recorded the data with a frequency of $1 \mathrm{~s}$. The time during which the temperature remained above $60^{\circ} \mathrm{C}$ in the inner bark (t60) and the time during which the temperature remained above $300{ }^{\circ} \mathrm{C}$ in the bark surface (t300) were calculated with data recorded. Maximum scorch height (SMx) (hypsometer VERTEX IV) was recorded to evaluate fire severity in the trunk [51,52]. The main parameters measured during prescribed burning in the selected trees are shown in Table 2.

Table 2. Main parameters measured during prescribed burning in mixed and pure stands of P. nigra. Data from [35].

\begin{tabular}{|c|c|c|c|c|c|c|c|c|}
\hline$S$ & PT & $\mathrm{T}$ & $\mathbf{R H}$ & WS & RS & FLI $^{1}$ & FH & $\mathrm{FL}^{1}$ \\
\hline- & - & ${ }^{\circ} \mathrm{C}$ & $\%$ & $\mathrm{~m} \mathrm{~s}^{-1}$ & $m \min ^{-1}$ & $\mathrm{~kW} \mathrm{~m}^{-1}$ & $\mathrm{~cm}$ & $\mathrm{~cm}$ \\
\hline $\begin{array}{l}\text { Mixed } \\
\text { stand }\end{array}$ & $\begin{array}{l}\text { Spring } \\
\text { burning }\end{array}$ & $\begin{array}{l}21.5 \\
(1.2)\end{array}$ & $\begin{array}{l}47.7 \\
(5.3)\end{array}$ & $\begin{array}{c}0.8 \\
(0.6)\end{array}$ & $\begin{array}{c}0.65 \\
(0.21)\end{array}$ & $\begin{array}{l}20.0 \\
(8.8)\end{array}$ & $\begin{array}{c}53 \\
(15)\end{array}$ & $\begin{array}{l}30 \\
(6)\end{array}$ \\
\hline $\begin{array}{l}\text { Mixed } \\
\text { stand }\end{array}$ & $\begin{array}{l}\text { Autumn } \\
\text { burning }\end{array}$ & $\begin{array}{l}11.9 \\
(0.4)\end{array}$ & $\begin{array}{l}67.0 \\
(1.3)\end{array}$ & $\begin{array}{c}0.3 \\
(0.3)\end{array}$ & $\begin{array}{c}0.59 \\
(0.31)\end{array}$ & $\begin{array}{l}11.2 \\
(6.6)\end{array}$ & $\begin{array}{c}17 \\
(10)\end{array}$ & $\begin{array}{l}23 \\
(6)\end{array}$ \\
\hline Pure stand & $\begin{array}{l}\text { Spring } \\
\text { burning }\end{array}$ & $\begin{array}{l}20.4 \\
(1.5)\end{array}$ & $\begin{array}{l}32.7 \\
(2.3)\end{array}$ & $\begin{array}{c}0.8 \\
(0.1)\end{array}$ & $\begin{array}{c}0.76 \\
(0.24)\end{array}$ & $\begin{array}{c}32.6 \\
(13.3)\end{array}$ & $\begin{array}{l}43 \\
(8)\end{array}$ & $\begin{array}{l}38 \\
(8)\end{array}$ \\
\hline Pure stand & $\begin{array}{l}\text { Autumn } \\
\text { burning }\end{array}$ & $\begin{array}{l}12.0 \\
(0.9)\end{array}$ & $\begin{array}{l}43.5 \\
(0.8)\end{array}$ & $\begin{array}{c}0.1 \\
(0.1)\end{array}$ & $\begin{array}{c}0.72 \\
(0.22)\end{array}$ & $\begin{array}{c}13.8 \\
(10.7)\end{array}$ & $\begin{array}{c}26 \\
(13)\end{array}$ & $\begin{array}{l}25 \\
(9)\end{array}$ \\
\hline
\end{tabular}

${ }^{1}$ Data from [53]. S: type of stand; PT: plot treatment; T: air temperature; RH: relative humidity; WS: wind speed; RS: fire rate of spread; FLI: fire-line intensity; FH: flame height; FL: flame length. Standard deviation in brackets.

\subsection{Litterfall: Fire Severity at Stand Level}

Immediately after the prescribed burning, 8 litterfall collectors $\left(0.38 \mathrm{~m}^{2}\right)$ were installed in each plot (total $n=144$ ) to evaluate fire severity at stand level (crown damage). In order to ensure the representativeness of the samples. The litterfall collection system was designed in accordance with the recommendations and parameters outlined in the Manual of the United Nations Economic Commission for Europe (UNECE), under the project entitled "International Co-operative Program on Assessment and Monitoring of Air Pollution Effects on Forests" (ICP Forests, Level II Plots) [54] to guarantee the quality and quantity of the sample (for more details, see [48]). On each collection day, the samples were 
transported to the laboratory and oven-dried at $65^{\circ} \mathrm{C}$ to constant weight. Litterfall biomass was collected during the year immediately after spring burning and autumn burning in mixed and pure stands and used to characterize fire severity at stand level [43,46,48].

\subsection{Tree-Ring Width Analysis}

In November 2018 (30 months after spring burning and 24 months after autumn burning), one core was extracted from each selected $P$. nigra tree at breast height ( $n=135$ in each stand; they were the same trees used to estimate burn severity at tree level), perpendicular to the terrain slope, with an increment borer $(0.5 \mathrm{~cm}$ inner diameter) [22]. All cores were prepared following standard dendrochronological techniques [55]. The cores were mounted on grooved boards and sanded until the tree rings were clearly visible.

Tree ring widths were measured using a tree ring measuring stage with a precision of $0.01 \mathrm{~mm}$ (Lintab ${ }^{\mathrm{TM}}$, Rinntech, Heidelberg, Germany) and recorded in a computer with TSAP software [56]. Our study species at our study site formed clearly defined rings boundaries with abrupt transitions between late wood and early wood [57]. All cores were dated and visually cross-dated to detect the presence of false and incomplete rings. COFECHA software was used to check cross-dating and validate measurement quality [58] (Table 3). The ring widths were converted into annual basal area increments (BAI) by using the equation BAI $=\pi\left(\mathrm{r}^{2} \mathrm{t}-\mathrm{r}^{2}(\mathrm{t}-1)\right)$, where " $\mathrm{r}$ " is the tree radius and " $\mathrm{t}$ " is the year of tree-ring formation. BAI was used as a proxy for tree growth because it is less dependent on age and thus prevents the need for detrending [59], which could also remove low frequency variability. In addition, the BAI was standardized and shown in box plots. The standardization was performed using the mean tree growth value of the immediately five preceding years unaffected by the burning treatment (2010-2015).

Table 3. Main dendrochronology statistics.

\begin{tabular}{cccc}
\hline- & Both Stands & Mixed Stand & Pure Stand \\
\hline Series intercorrelation & 0.439 & 0.542 & 0.431 \\
Average mean sensitivity & 0.337 & 0.374 & 0.308 \\
\hline
\end{tabular}

\subsection{Statistical Analysis}

The following three models were constructed in order to analyze the tree growth results: model $\mathrm{SB}$, for spring burned plots; model $\mathrm{AB}$, for autumn-burned plots; and model NB, for non-burned plots. For each treatment, a linear mixed model (Equation (1)) was used to describe short-term impact of $\mathrm{PB}$ on tree growth. BAI was selected as the target variable. A collinearity analysis was performed; tree height $(\mathrm{H})$, which had a strong collinearity with $\mathrm{DBH}$, was excluded. Likewise, nested effect between random variables were considered. According to the collinearity and significance, the best fit model considered the following potential predictors (fixed factors) (Table 4): tree height $(\mathrm{H})$, percentage of live crown height $(\mathrm{Hc})$, diameter at breast height (DBH), maximum scorch height (SMx), time during which the temperature in the cambium area was higher than $60^{\circ} \mathrm{C}$ (t60) and time during which the temperature in the bark surface was higher than $300{ }^{\circ} \mathrm{C}(\mathrm{t} 300)$. Possible differences in composition and characteristics of stand (S), variability between plots $(\mathrm{P})$ and total amount of litterfall collected per plot one year after PB (L) were resolved by adding a random effect.

$$
\ln \left(B A I_{k(j y)}+1\right)=\beta_{0}+\beta_{1} \cdot H c+\beta_{2} \cdot D B H+\beta_{3} \cdot S M x+\beta_{4} \cdot t 60+\beta_{5} \cdot t 300+\gamma_{0 k(j)}+\alpha_{0 k(j)}+L \alpha_{k(j y)}+\varepsilon_{k(j y)}
$$

where $\beta_{0}$ is the overall intercept; $\beta_{i}(i=1, \ldots, 5)$ are the parameters adjusting the fixed effects; $k$ is the study site index; $k(j)$ is the tree index nested in the study site; $y$ is the month of measurement index; $\gamma_{0 k(j)}, \alpha_{0 k(j)}$ represents the random effects associated with study plots and stand, respectively; $L \alpha_{k(j y)}$ is the interaction between stand and litterfall; and $\varepsilon_{k(j y)}$ is the error term. No pattern was observed in the residuals of any models. 
Table 4. Main variables used to model the impact of prescribed burning on tree growth.

\begin{tabular}{|c|c|c|c|c|c|c|c|c|c|}
\hline$S$ & PT & $\mathbf{H}$ & Hc & DBH & SMx & t60 & t300 & L16 & L17 \\
\hline- & - & $\mathbf{m}$ & $\%$ & $\mathrm{~cm}$ & $\mathrm{~cm}$ & $\mathrm{~s}$ & $\mathbf{s}$ & $\mathrm{kg} \mathrm{ha}^{-1}$ & $\mathrm{~kg} \mathrm{ha}^{-1}$ \\
\hline $\begin{array}{l}\text { Mixed } \\
\text { stand }\end{array}$ & $\begin{array}{c}\text { No } \\
\text { burning }\end{array}$ & $\begin{array}{l}12.2 \\
(5.0)\end{array}$ & $\begin{array}{c}50.3 \\
(16.2)\end{array}$ & $\begin{array}{c}19.5 \\
(10.3)\end{array}$ & - & - & - & $\begin{array}{l}3171 \\
(649)\end{array}$ & $\begin{array}{l}3532 \\
(585)\end{array}$ \\
\hline $\begin{array}{c}\text { Mixed } \\
\text { stand }\end{array}$ & $\begin{array}{l}\text { Spring } \\
\text { burning }\end{array}$ & $\begin{array}{l}11.9 \\
(5.0) \\
\end{array}$ & $\begin{array}{c}48.0 \\
(15.2)\end{array}$ & $\begin{array}{c}18.1 \\
(10.0)\end{array}$ & $\begin{array}{c}54 \\
(50)\end{array}$ & $\begin{array}{c}31 \\
(82)\end{array}$ & $\begin{array}{c}10 \\
(26)\end{array}$ & $\begin{array}{l}3257 \\
(599)\end{array}$ & - \\
\hline $\begin{array}{l}\text { Mixed } \\
\text { stand }\end{array}$ & $\begin{array}{l}\text { Autumn } \\
\text { burning }\end{array}$ & $\begin{array}{l}12.2 \\
(5.2)\end{array}$ & $\begin{array}{c}50.1 \\
(15.8)\end{array}$ & $\begin{array}{c}19.4 \\
(10.4)\end{array}$ & $\begin{array}{c}46 \\
(45)\end{array}$ & $\begin{array}{c}16 \\
(59)\end{array}$ & $\begin{array}{c}6 \\
(20)\end{array}$ & - & $\begin{array}{l}2732 \\
(325)\end{array}$ \\
\hline $\begin{array}{l}\text { Pure } \\
\text { stand }\end{array}$ & $\begin{array}{c}\text { No } \\
\text { burning }\end{array}$ & $\begin{array}{l}13.1 \\
(4.9)\end{array}$ & $\begin{array}{c}39.4 \\
(14.4)\end{array}$ & $\begin{array}{c}19.6 \\
(10.1)\end{array}$ & - & - & - & $\begin{array}{l}1989 \\
(519)\end{array}$ & $\begin{array}{l}2393 \\
(739)\end{array}$ \\
\hline $\begin{array}{l}\text { Pure } \\
\text { stand }\end{array}$ & $\begin{array}{l}\text { Spring } \\
\text { burning }\end{array}$ & $\begin{array}{l}13.9 \\
(4.4)\end{array}$ & $\begin{array}{c}37.9 \\
(15.1)\end{array}$ & $\begin{array}{l}19.5 \\
(9.4)\end{array}$ & $\begin{array}{c}167 \\
(201)\end{array}$ & $\begin{array}{c}23 \\
(93)\end{array}$ & $\begin{array}{c}44 \\
(167)\end{array}$ & $\begin{array}{l}3482 \\
(129)\end{array}$ & - \\
\hline $\begin{array}{l}\text { Pure } \\
\text { stand }\end{array}$ & $\begin{array}{l}\text { Autumn } \\
\text { burning }\end{array}$ & $\begin{array}{l}14.5 \\
(5.3)\end{array}$ & $\begin{array}{c}36.2 \\
(12.5)\end{array}$ & $\begin{array}{c}21.7 \\
(11.3)\end{array}$ & $\begin{array}{c}132 \\
(169)\end{array}$ & $\begin{array}{c}16 \\
(81)\end{array}$ & $\begin{array}{c}33 \\
(149)\end{array}$ & - & $\begin{array}{l}3629 \\
(527)\end{array}$ \\
\hline
\end{tabular}

S: type of stand; PT: plot treatment; H: tree height; Hc: percentage of live crown height; DBH: diameter at breast height; SMx: maximum scorch height; t60: time during which the temperature in the cambium area was higher than $60^{\circ} \mathrm{C}$; t300: time during which the temperature in the bark surface was higher than $300^{\circ} \mathrm{C}$; L16: litterfall biomass from May 2016 to April 2017; L17: litterfall biomass from November 2016 to October 2017. Standard deviation in brackets.

All statistical tests were performed using R software (v. 3.0.1, R Foundation for Statistical Computing), specifically with the nlme and lme4 packages for linear mixedeffects modelling. A significance level of $95 \%$ was established for detecting differences between treatments.

\section{Results}

The annual trends in the mean basal area increment (BAI) for the three treatments in the mixed and pure stand were similar (Figure 2). However, tree growth was lower in the spring burned plots in the mixed stand than in the unburned and autumn burned plots (Figure 2a). Hence, the BAI was standardized and shown in box plots per type of stand (mixed or pure) for the comparison of tree growth (Figures 3 and 4). In both stands, tree growth was lower after spring burning (Figures 3 and 4). The same trend of slight reduction on tree growth was observed in the pure stand one year after autumn burning (Figure 4). Conversely, in the mixed stand, a scarce impact on tree growth was shown in the year following autumn burning (Figure 3).

The type of stand (mixed or pure) did not have an influence on tree growth (Table 5). The tree variables, percentage of live crown height and diameter at breast height, were significant factors in the three models (although the percentage of live crown height in Model NB was not significant; $p<0.1$ ) (Table 5). Regarding the fire severity variables at the tree and stand level (maximum scorch height, time during which temperature in the cambium area was higher than $60^{\circ} \mathrm{C}$, time during which temperature in the bark surface was higher than $300^{\circ} \mathrm{C}$ and litterfall biomass), the maximum scorch height was a significant factor (Model SB and AB). A higher scorch height is related to a greater fire severity, which may negatively influence tree growth. The time during which the temperature in the bark surface was higher than $300{ }^{\circ} \mathrm{C}$ was only significant in Model SB, as well as t60, which was significant in the same model. In this sense, the spring burning appeared to have a greater effect on tree growth than the autumn burning. The values of the variables related with the residence time above lethal temperatures did not have an impact on the autumn burning due to the low intensity of the fire. Litterfall was not a significant factor in any of the models. 


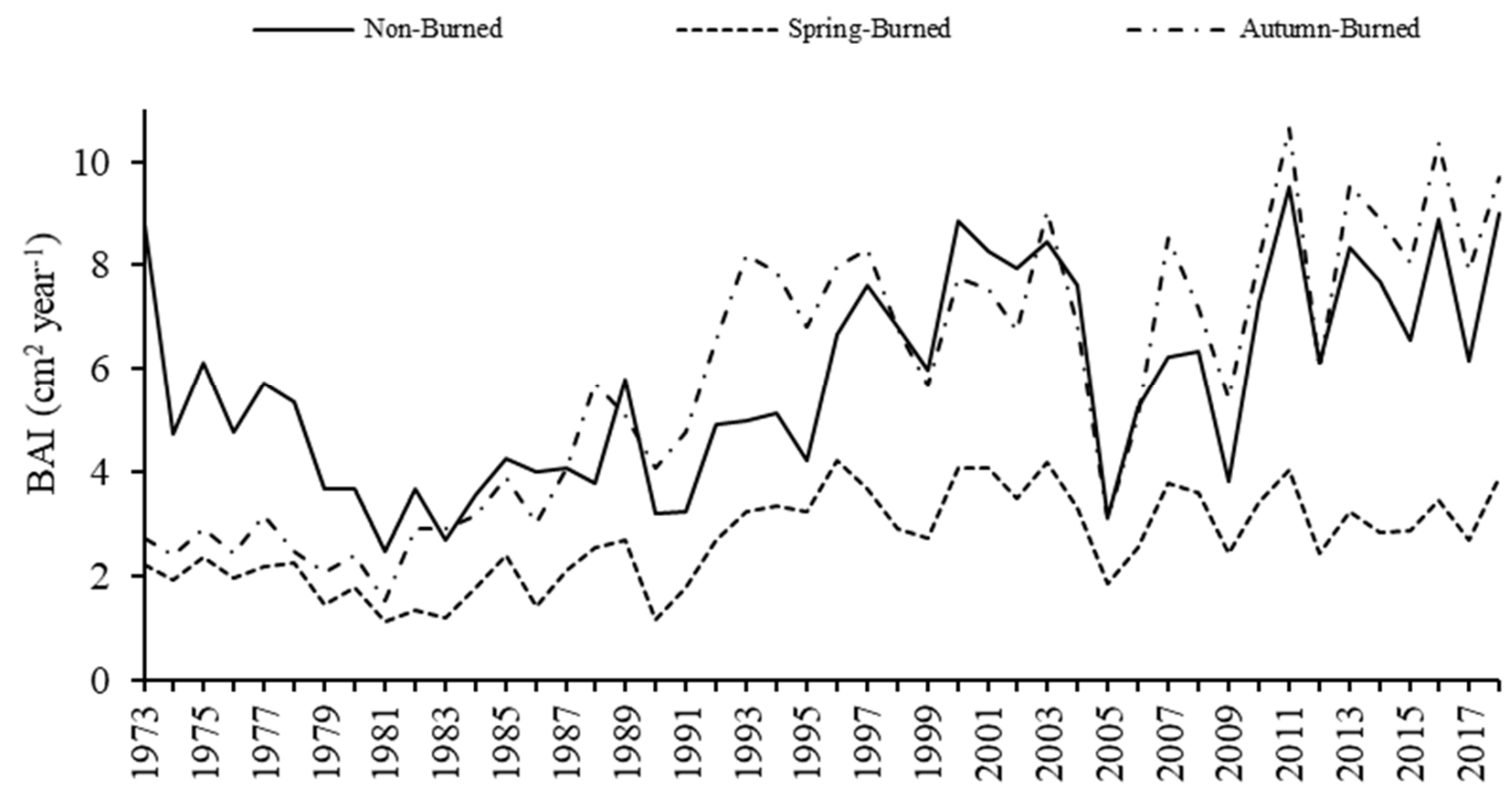

(a) Mixed stand

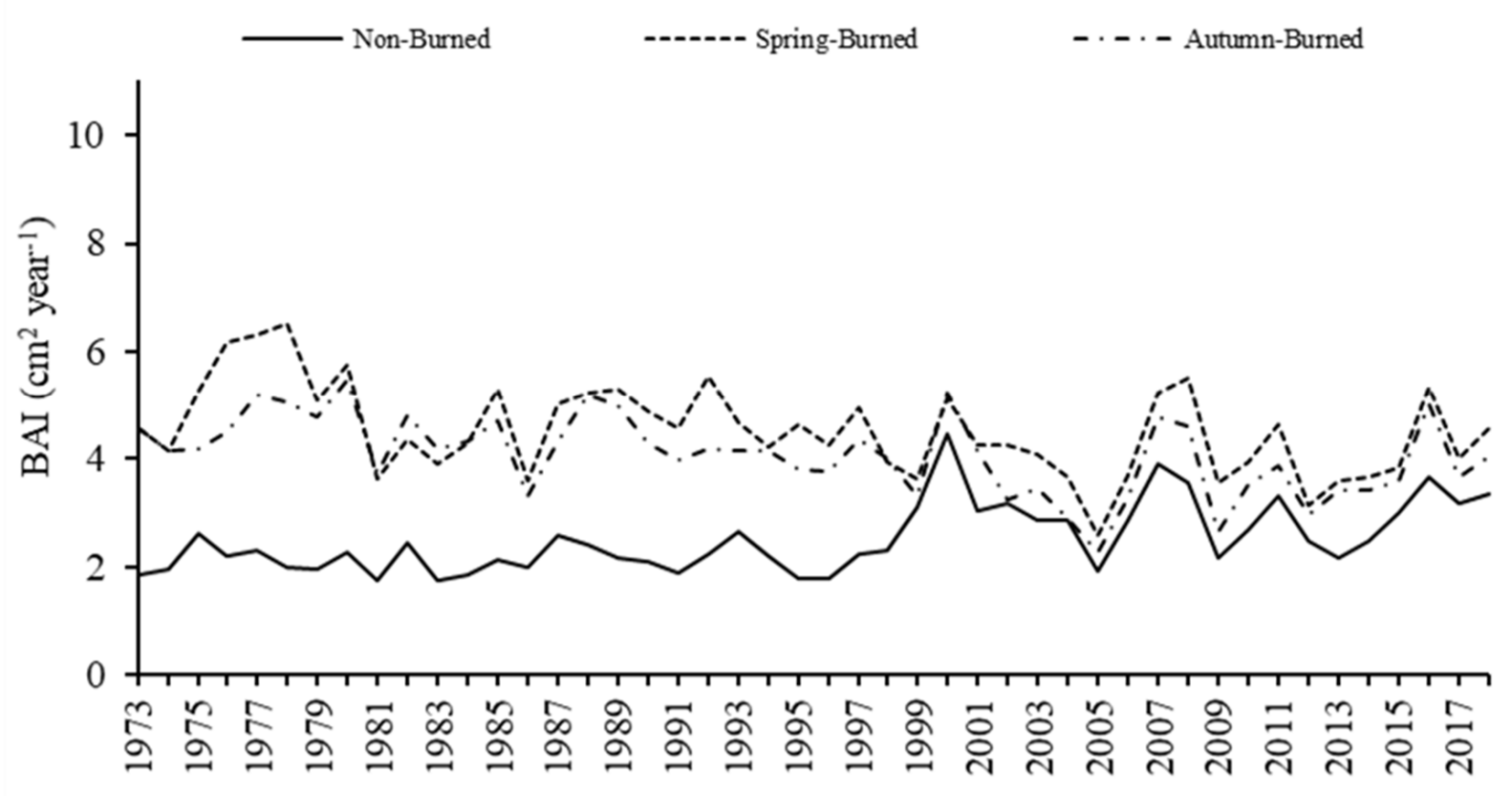

(b) Pure stand

Figure 2. Comparison of annual trends in mean basal area increment (BAI) in (a) the mixed stand and in (b) the pure stand. Unburned plots (solid line), spring-burned plots (dashed line) and autumn-burned plots (dotted line). Spring burning was conducted in May 2016, autumn burning was carried out in November 2016. 


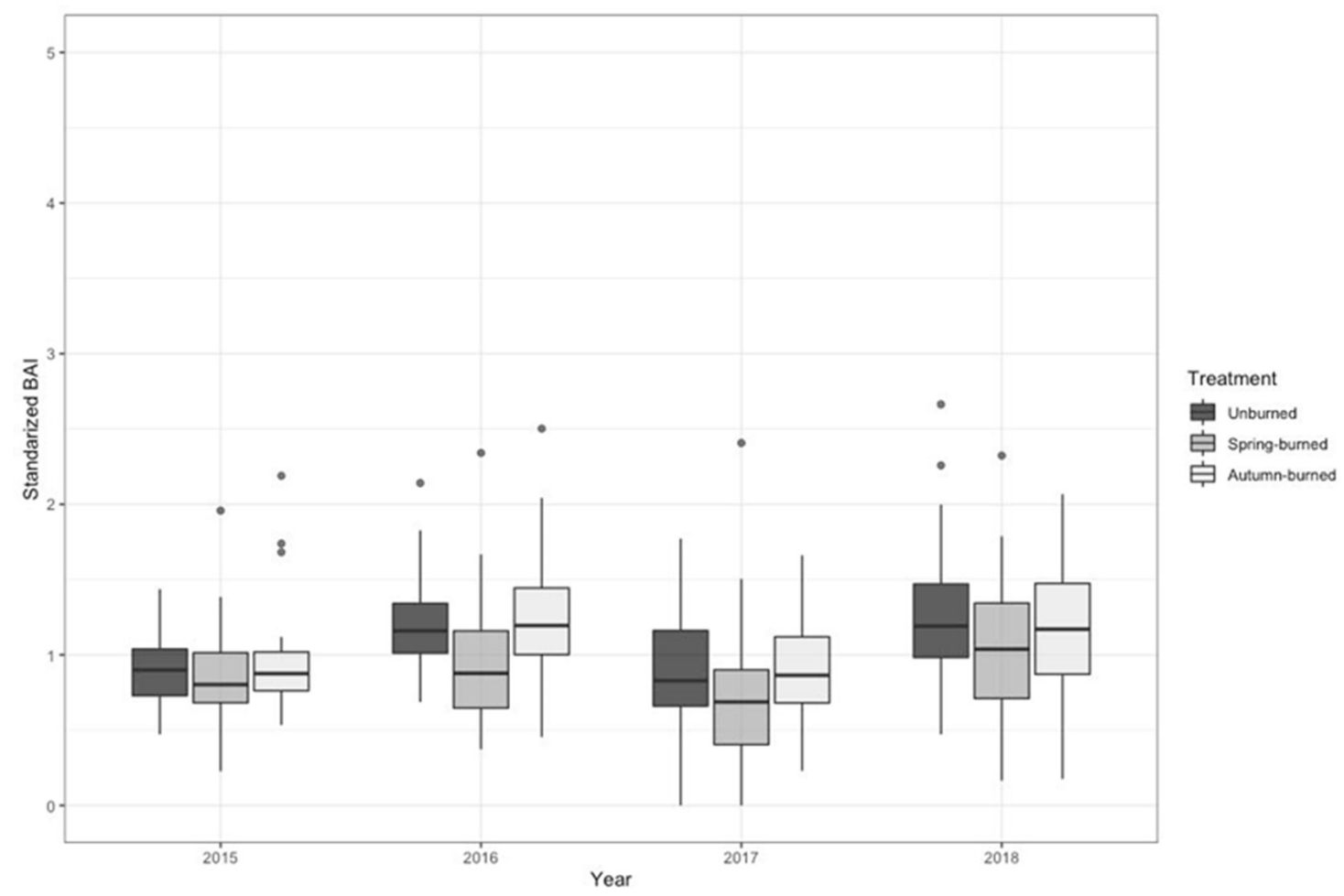

Figure 3. Box plot showing the differences in standardized BAI in the mixed stand. Spring burning was conducted in May 2016, autumn burning was carried out in November 2016.

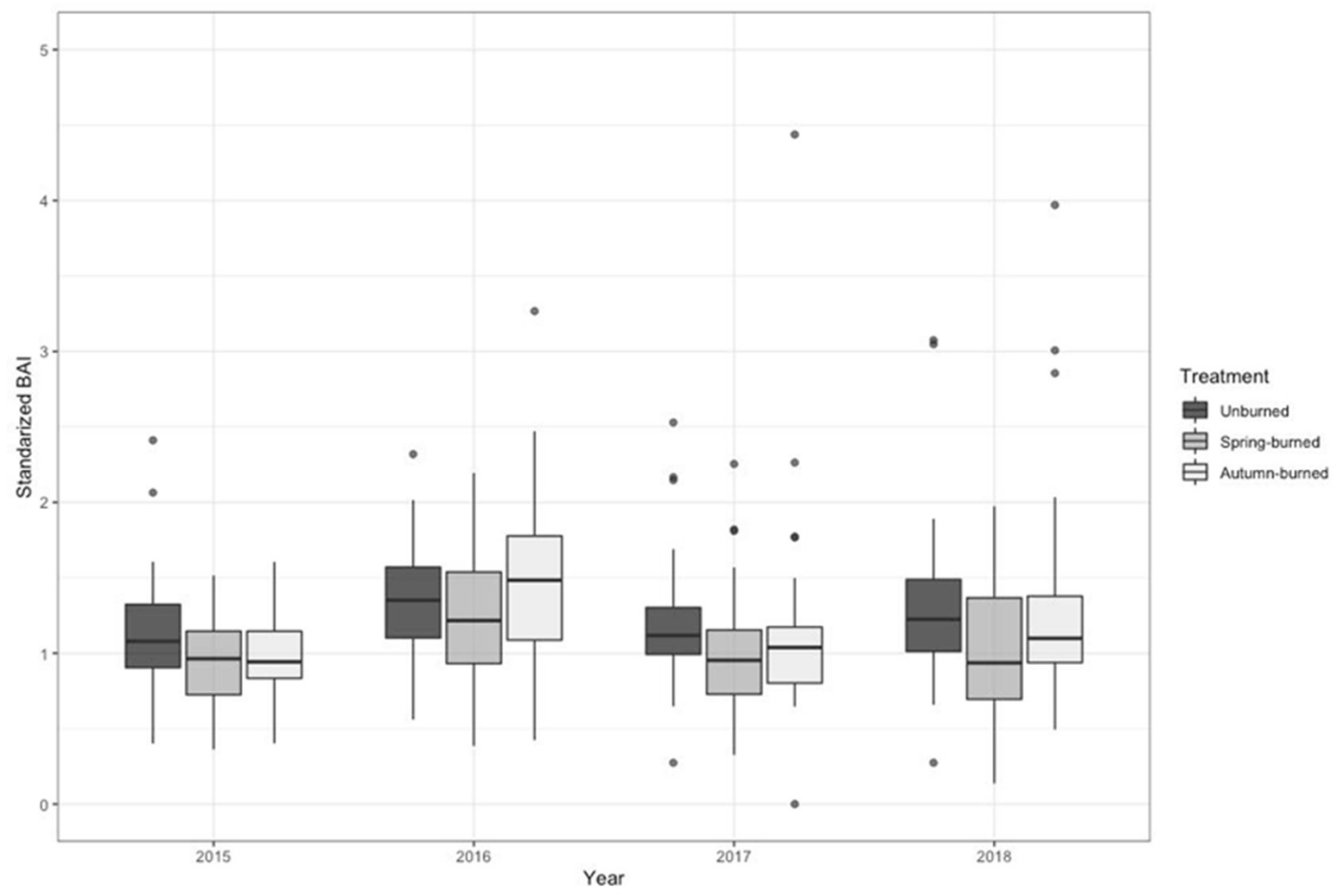

Figure 4. Box plot showing the differences in standardized BAI in the pure stand. Spring burning was conducted in May 2016, autumn burning was carried out in November 2016. 
Table 5. Summary of statistical results.

\begin{tabular}{|c|c|c|c|c|c|c|c|c|c|c|c|c|}
\hline \multirow[t]{2}{*}{$\begin{array}{l}\text { Fixed } \\
\text { Effects }\end{array}$} & \multicolumn{4}{|c|}{ Model SB } & \multicolumn{4}{|c|}{ Model AB } & \multicolumn{4}{|c|}{ Model NB } \\
\hline & Estimate & SE & $\begin{array}{c}t \\
\text { Value }\end{array}$ & $\begin{array}{c}p \\
\text { Value }\end{array}$ & Estimate & SE & $\begin{array}{c}t \\
\text { Value }\end{array}$ & $\begin{array}{c}p \\
\text { Value }\end{array}$ & Estimate & SE & $\begin{array}{c}t \\
\text { Value }\end{array}$ & $\begin{array}{c}p \\
\text { Value }\end{array}$ \\
\hline Intercept & $1.364 \times 10^{1}$ & $6.925 \times 10^{-2}$ & 19.696 & $<0.001$ & $1.297 \times 10^{1}$ & $9.274 \times 10^{-2}$ & 13.988 & 0.0026 & $1.488 \times 10^{1}$ & $1.397 \times 10^{-1}$ & 10.653 & 0.0087 \\
\hline $\mathrm{Hc}$ & $6.541 \times 10^{-2}$ & $9.378 \times 10^{-3}$ & 6.974 & $<0.001$ & $5.233 \times 10^{-2}$ & $1.221 \times 10^{-2}$ & 4.285 & $<0.001$ & $1.855 \times 10^{-2}$ & $1.068 \times 10^{-2}$ & 1.738 & 0.0824 \\
\hline DBH & $6.448 \times 10^{-1}$ & $9.864 \times 10^{-3}$ & 65.367 & $<0.001$ & $6.619 \times 10^{-1}$ & $8.516 \times 10^{-3}$ & 77.728 & $<0.001$ & $5.093 \times 10^{-1}$ & $1.037 \times 10^{-2}$ & 49.138 & $<0.001$ \\
\hline SMx & $-3.762 \times 10^{-2}$ & $8.500 \times 10^{-3}$ & -4.426 & $<0.001$ & $-2.291 \times 10^{-1}$ & $3.092 \times 10^{-2}$ & -7.411 & $<0.001$ & - & - & - & - \\
\hline t60 & $-1.264 \times 10^{-2}$ & $5.560 \times 10^{-3}$ & -2.273 & 0.0231 & $-1.790 \times 10^{-1}$ & $1.175 \times 10^{-1}$ & -1.524 & 0.1277 & - & - & - & - \\
\hline $\mathrm{t} 300$ & $-2.796 \times 10^{-2}$ & $6.159 \times 10^{-3}$ & -4.540 & $<0.001$ & $-1.039 \times 10^{-1}$ & $7.387 \times \times 10^{-2}$ & -1.406 & 0.1598 & - & - & - & - \\
\hline $\begin{array}{l}\text { Random } \\
\text { effects }\end{array}$ & \multicolumn{4}{|c|}{ Model SB } & \multicolumn{4}{|c|}{ Model AB } & \multicolumn{4}{|c|}{ Model NB } \\
\hline & Variance & $\mathrm{SE}$ & \multicolumn{2}{|c|}{$\operatorname{Pr}(>$ Chisq $)$} & Variance & $\mathrm{SE}$ & \multicolumn{2}{|c|}{$\operatorname{Pr}(>$ Chisq $)$} & Variance & $\mathrm{SE}$ & \multicolumn{2}{|c|}{$\operatorname{Pr}(>$ Chisq) } \\
\hline $\mathrm{s}$ & 0.0000 & 0.0000 & \multirow{2}{*}{\multicolumn{2}{|c|}{1.0000}} & 0.0030 & 0.0554 & \multicolumn{2}{|c|}{0.8590} & 0.0287 & 0.1696 & \multicolumn{2}{|c|}{0.2553} \\
\hline $\mathrm{P}$ & 0.0177 & 0.1330 & & & 0.0190 & 0.1379 & \multicolumn{2}{|c|}{1.0000} & 0.0013 & 0.0364 & \multicolumn{2}{|c|}{$\begin{array}{l}0.2503 \\
1.0000\end{array}$} \\
\hline $\mathrm{L}$ & 0.0105 & 0.1028 & \multicolumn{2}{|c|}{$\begin{array}{l}1.0000 \\
1.0000\end{array}$} & 0.0188 & 0.1373 & \multicolumn{2}{|c|}{1.0000} & 0.0287 & 0.1696 & \multicolumn{2}{|c|}{1.0000} \\
\hline
\end{tabular}

Hc: percentage of live crown height; DBH: diameter at breast height; SMx: maximum scorch height; t60: time during which the temperature in the cambium area was higher than $60^{\circ} \mathrm{C}$; t300: time during which the temperature in the bark surface was higher than $300^{\circ} \mathrm{C}$; S: type of stand; P: plot; L: accumulated litterfall during the year following the burning treatment; SE: standard error. Values shown in bold indicate significant effects $(p<0.05)$.

\section{Discussion}

The study findings highlight the importance of modelling tree growth response to $\mathrm{PB}$ as a function stand and tree characteristics, fire season and fire severity variables to gain some insight into individual tree responses. As far as we know, this the first time that variables associated with fire severity, such as the time of exposure to a critical temperature in the bark surface and cambium area and the effect of litterfall after PB, have been included in a model of tree growth response to prescribed burning. These variables play a key role in determining the stress level in trees after fire and they may be essential to enable the estimation of post-burn growth and mortality rate [60].

The findings showed that prescribed burning at a short-term scarcely affected tree growth. Similar findings have been reported by other authors (e.g., [16,61,62]). In springburned plots in the mixed stand, and in spring- and autumn-burned plots in the pure stand, a decrease in tree growth was observed after burning. The trend in the reduction in tree growth has generally been described as short-term (1-3 years), with growth rates returning to approximately pre-fire levels thereafter [63]. The reduced growth of Pinus ponderosa, $P$. contorta and P. palustris has been observed one and two years after burning by [64-66], respectively. Although, other authors pointed to an increase in tree growth after burnings, mainly because fire acts as a mineralizing agent releasing nutrients instantaneously, in contrast to slower natural decomposition processes [67-69]. However, such nutrient pulses are usually temporary, and the values return to or fall below pre-treatment values within 1-2 years [61]. However, other longer growth recovery rates have also been reported, such as the slight decline in tree growth observed 6 years after fire in Pinus ponderosa and Pinus sylvestris $[70,71]$.

The present findings did not allow for confirmation of a lower disturbance on tree growth after prescribed burning or a faster recovery in a mixed stand compared to pure stands. Nevertheless, several authors have reported that mixed stands are more stable than pure stands, e.g., [72-74]. Even studies involving soil properties and litterfall carried out in the same experimental plots $[43,48]$ have revealed this positive effect on mixed stands after prescribed burning.

Although there is an abundant literature relating growth responses to climate and to the potential decline in vitality in Mediterranean forests, e.g., [75,76], the relationships may depend on many stand- and tree-level factors [24,77]. Our study findings showed that the tree variables included in statistical analysis (percentage of live crown height and DBH) are significant factors in all three models (although the percentage of live crown height showed less significance in Model non-burned). Therefore, regardless of the type of stand (mixed or pure), the particular characteristics of each tree may explain the variability in growth after fire. This may be partly explained by the low percentage of Pinus pinaster in the mixed stand or the low intensity of burning. In this regard, some researchers proposed that factors 
affecting tree growth rate before fire continue to affect post-fire growth (e.g., [64]), although others have suggested the opposite [70].

The maximum scorch height was a significant variable that negatively influenced tree growth after spring and autumn burning. It is, therefore, possible that higher scorch heights may imply greater added stress on trees and should, therefore, be avoided. Indeed, firedamaged trees require stored carbohydrates to replenish tissues, depleting carbohydrate reserves, often compromising tree growth [60]. Despite these results, maximum scorch height proved to be a random variable regarding litterfall in the same experimental plots, although it was probably due to the fact that the maximum scorch height was reached below the mean height of the first live branch [43].

The time during which the temperature remained above $300{ }^{\circ} \mathrm{C}$ in the bark surface had a significant response regarding tree growth only during spring PB; in addition, the time during which the temperature remained above $60^{\circ} \mathrm{C}$ in the inner bark (cambium area) was also significant during spring PB. Although, as mentioned, the maximum scorch was a significant variable after spring and autumn burning treatments, it seemed to have a slightly greater effect after spring PB. Overall, spring burning has been described to be more disruptive to trees because carbohydrate reserves are at their lowest levels at the beginning of the annual growth period [18,19]. Furthermore, a higher level of damage to fine roots (abundant during this period) has been pointed out $[78,79]$. Hence, PB carried out in autumn seemed to have less of an impact on tree growth; however, the disturbance in other tree and stand processes (e.g., impact on litterfall) should be also considered in the prescription plans [43]. In this regard, fuels have been described as typically drier later in the year [20], which corresponds with the regular autumn burning season, which may imply higher mortality rates [21]. The relationship between tree growth and t60 may be because the insulating capacity of bark completely protects the cambium at a low-intensity PB [35]. Pinus nigra is known to possess thick bark (especially in the lowest part of stem), as a result of the adaptation to frequent surface fires, which protects the cambium against overheating by fire (e.g., $[29,80,81])$. In addition, the bole scorch height does not necessarily imply an effect on the cambium if it does not affect the entire bole circumference [63], which in turn disturbs the supply of water and nutrients to the leaves and the translocation of photosynthates to the roots [82]. Furthermore, [62] also suggested that the minimal presence of fire scars associated with heat damage to the cambium and other live tissues does not significantly affect tree growth. However, this reflected the importance of including variables associated with the flame residence time in the tree growth models.

The total litterfall biomass collected one year after prescribed burning was not a significant variable in the tree growth response. The low-intensity of the prescribed burning and the high height of the first live branch may explain the weak significance of this variable. Nevertheless, litterfall was found to be beneficial to tree growth, in some cases. In this regard, PB improves tree efficiency by eliminating the unproductive lower branches [41] and less efficient needles from the lower part of the crown [39], which may enhance tree growth $[83,84]$. Or, by contrast, fire disturbance in the crown is typically related to the reduction in tree growth [70], which represents photosynthetically active tissue and a source of energy (e.g., [38,85]). Indeed, some authors maintain that allocation of resources prioritizes foliage and buds [86-88]; therefore, an increase in litterfall may mobilize resources in these parts (mainly to guarantee photosynthesis) at the expense of tree growth. However, the findings obtained did not allow us to confirm the significance of this variable on tree growth, at least in the short-term.

\section{Conclusions}

The findings suggest that $\mathrm{PB}$ (spring and autumn) is a potentially valuable management tool for reducing fire hazard, with a scarce effect on short-term tree growth. The overall trend was for a reduction in growth. A longer-term study may be necessary to establish the recovery rate of the stands, particularly in a pure stand. The differences 
between the mixed and pure stands were not critical to tree growth, which do not allow for a confirmation of the initial hypothesis about the weaker effect of perturbation in the mixed stand. Individual tree characteristics proved to be more important for growth than the type of stand, treatment or fire severity in low-intensity PB. The differences between the burning seasons were notable. The inclusion of some post-burn severity variables for the first time in tree growth models showed that the maximum scorch height influences tree growth. This is an easily measurable variable that must be considered in burning prescriptions. The recognized surface fire adaptations of Pinus nigra, such as the insulating capacity of the thick bark and the high crown height, completely protected the tree; however, special attention should be given to the variables related to exposition to a critical temperature in the outer and inner bark, particularly after spring burning. Although autumn prescribed burning seemed to have less of an impact on tree growth, disturbance in the other stand dynamics should be also considered. The litterfall biomass one year after prescribed burning was not a significant variable for tree growth. These findings could be used to improve burn prescriptions and the evaluation of PB in P. nigra stands.

Author Contributions: J.E. designed the experiment, carried out the field and laboratory work, ran the data analysis, discussed the results and wrote the manuscript. D.M.-B. carried out the laboratory work and corrected the manuscript. Ó.R.d.R. supported the statistical analysis and corrected the manuscript. C.H. designed the experiment, carried out the field work and corrected the manuscript. M.G. designed the experiment, carried out the field work and corrected the manuscript. J.M. designed the experiment, carried out the field work, corrected the manuscript and coordinated the research project. All authors have read and agreed to the published version of the manuscript.

Funding: This study was supported by the Spanish R\&D GEPRIF projects (Fire Severity Reduction through New Tools and Technologies for Integrated Forest Fire Protection Management) and VIS4FIRE (Integrated Vulnerability of Forest Systems to Wildfire: Implications on Forest Management Tools) (RTA2014-00011-C06-01 and RTA2017-00042-C05-01). GEPRIF and VIS4FIRE are co-funded by the EU through the FEDER program. This study was also co-financed by INIA (FPI-SGIT 2015) and the European Social Fund through a grant awarded to Juncal Espinosa. Dario Martin-Benito was funded by projects AGL2015-73190-JIN, RYC-2017-23389 and PID2019-110273RB-I00.

Institutional Review Board Statement: Not applicable.

Informed Consent Statement: Not applicable.

Data Availability Statement: Not applicable.

Acknowledgments: We are grateful to Cristina Carrillo, Carmen Díez and Ana Carmen de la Cruz (CSIC-INIA) for assistance during the study, to members of the Cuenca Fire Service (SEIF Cuenca), who conducted the prescribed burning, and to The State Meteorological Agency of Spanish Government (AEMET) for providing meteorological data.

Conflicts of Interest: The authors declare that there is no conflict of interest.

\section{References}

1. Moritz, M.A.; Stephens, S.L. Fire and sustainability: Considerations for California's altered future climate. Clim. Chang. 2008, 87, 265-271. [CrossRef]

2. Seidl, R.; Thom, D.; Kautz, M.; Martin-Benito, D.; Peltoniemi, M.; Vacchiano, G.; Wild, J.; Ascoli, D.; Petr, M.; Honkaniemi, J.; et al. Forest disturbances under climate change. Nat. Clim. Chang. 2017, 7, 395-402. [CrossRef] [PubMed]

3. Fernandes, P.M.; Botelho, H.S. A review of prescribed burning effectiveness in fire hazard reduction. Int. J. Wildland Fire 2003, 12, 117-128. [CrossRef]

4. Agee, J.K.; Skinner, C.N. Basic principles of forest fuel reduction treatments. For. Ecol. Manag. 2005, 211, 83-96. [CrossRef]

5. Piqué, M.; Domènech, R. Effectiveness of mechanical thinning and prescribed burning on fire behavior in Pinus nigra forests in NE Spain. Sci. Total Environ. 2018, 618, 1539-1546. [CrossRef]

6. Fernandes, P.M.; Davies, G.M.; Ascoli, D.; Fernandez, C.; Moreira, F.; Rigolot, E.; Stoof, C.; Vega, J.A.; Molina, D. Prescribed burning in southern Europe: Developing fire management in a dynamic landscape. Front. Ecol. Environ. 2013, 11, e4-e14. [CrossRef]

7. Ferreira, A.J.D.; Alegre, S.P.; Coelho, C.O.A.; Shakesby, R.A.; Pascoa, F.M.; Ferreira, C.S.S.; Keizer, J.J.; Ritsema, C. Strategies to prevent forest fires and techniques to reverse degradation process in burned areas. Catena 2015, 128, 224-237. [CrossRef] 
8. Shakesby, R.A.; Bento, C.P.M.; Ferreira, C.S.S.; Ferreira, A.J.D.; Stoof, C.R.; Urbanek, E.; Walsh, R.P.D. Impacts of soil loss on soil loss and soil quality: An assessment based on an experimentally-burned catchment in central Portugal. Catena 2015, 128, 278-293. [CrossRef]

9. Fernandes, P.; Rossa, C.; Madrigal, J.; Rigolot, E. Updated state of the art on the uses of prescribed burning. In Project FORESTERRA MedWildFireLab: "Global Change Impacts on Wildland Fire Behaviour and Uses in Mediterranean Forest Ecosystems, towards a «Wall Less" Mediterranean Wildland Fire Laboratory"; UTAD, INIA, INRA: Paris, France, 2016; p. 20.

10. Kerns, B.K.; Day, M.A. Prescribed fire regimes subtly alter ponderosa pine forest plant community structure. Ecosphere 2018, 9, e02529. [CrossRef]

11. Bär, A.; Michaletz, S.T.; Mayr, S. Fire effects on tree physiology. New Phytol. 2019, 223, 1728-1741. [CrossRef]

12. Nesmith, J.C.; Das, A.J.; O’Hara, K.L.; van Mantgem, P.J. The influence of prefire tree growth and crown condition on postfire mortality of sugar pine following prescribed fire in Sequoia National Park. Can. J. For. Res. 2015, 45, 910-919. [CrossRef]

13. Maringer, J.; Ascoli, D.; Küffer, N.; Schmidtlein, S.; Conedera, M. What drives European beech (Fagus sylvatica L.) mortality after forest fires of varying severity? For. Ecol. Manag. 2016, 368, 81-93. [CrossRef]

14. Thompson, M.T.; Koyama, A.; Kavanagh, K.L. Wildfire effects on physiological properties in conifers of central Idaho forests, USA. Trees 2017, 31, 545-555. [CrossRef]

15. Battipaglia, G.; Strumia, S.; Esposito, A.; Giuditta, E.; Sirignano, C.; Altieri, S.; Rutigliano, F.A. The effects of prescribed burning on Pinus halepensis Mill. as revealed by dendrochronological and isotopic analyses. For. Ecol. Manag. 2014, 334, 201-208. [CrossRef]

16. Valor, T.; González-Olabarria, J.R.; Piqué, M. Assessing the impact of prescribed burning on the growth of European pines. For. Ecol. Manag. 2015, 343, 101-109. [CrossRef]

17. Valor, T. The Effects of Prescribed Burning on the Vigour of Mediterranean pine species. Ph.D. Thesis, Universidad Autónoma de Barcelona, Barcelona, Spain, 2018; 199p.

18. Hough, W.A. Carbohydrate reserves of saw-palmetto: Seasonal variation and effects of burning. For. Sci. 1968, 14, $399-405$.

19. Garrison, G.A. Carbohydrate Reserves and Response to Use; General Technical Report GTR-INT-1; USDA Forest Service: New York, NY, USA, 1972.

20. Skinner, C.N.; Chang, C.R. Fire Regimes, Past and Present; Technical Report; Centers for Water and Wildland Resources, University of California Davis: Davis, CA, USA, 1996.

21. Thies, W.G.; Westlind, D.J.; Loewen, M. Season of prescribed burn in ponderosa pine forests in eastern Oregon: Impact on pine mortality. Int. J. Wildland Fire 2005, 14, 223-231. [CrossRef]

22. Fritts, H.C. Tree Rings and Climate London; Academic Press: London, UK, 1976.

23. Rossi, S.; Deslauriers, A.; Anfodillo, T.; Carrer, M. Age-dependent xylogenesis in timberline conifers. New Phytol. 2008, 177, 199-208. [CrossRef]

24. Lucas-Borja, M.E.; Vacchiano, G. Interactions between climate, growth and seed production in Spanish black pine (Pinus nigra Arn. ssp. salzmannii) forests in Cuenca Mountains (Spain). New For. 2018, 49, 399-414. [CrossRef]

25. DeClerck, F.A.J.; Barbour, M.G.; Sawyer, J.O. Species richness and stand stability in conifer forests of the Sierra Nevada. Ecology 2006, 87, 2787-2799. [CrossRef]

26. Lloret, F.; Lobo, A.; Estevan, H.; Maisongrande, P.; Vayreda, J.; Terradas, J. Woody plant richness and NDVI response to drought events in Catalonian (Notheastern Spain) forests. Ecology 2007, 88, 2270-2279. [CrossRef]

27. Klos, R.J.; Wang, G.G.; Bauerle, W.L.; Rieck, J.R. Drought impact on forest growth and mortality in the southeast USA: An analysis using Forest Health and Monitoring data. Ecol. Appl. 2009, 19, 699-708. [CrossRef]

28. Fernandes, P.M.; Vega, J.A.; Jimenez, E.; Rigolot, E. Fire resistance of European pines. For. Ecol. Manag. 2008, 256, 246-255. [CrossRef]

29. Fulé, P.Z.; Ribas, M.; Gutiérrez, E.; Vallejo, R.; Kaye, M.W. Forest structure and fire history in an old Pinus nigra forest, eastern Spain. For. Ecol. Manag. 2008, 255, 1234-1242. [CrossRef]

30. Pausas, J.G.; Llovet, J.; Rodrigo, A.; Vallejo, R. Are wildfires a disaster in the Mediterranean basin? A review. Int. J. Wildland Fire 2009, 17, 713-723. [CrossRef]

31. Tapias, R.; Gil, L.; Fuentes-Utrilla, P.; Pardos, J.A. Canopy seed banks in Mediterranean pines of south-eastern Spain: A comparison between Pinus halepensis Mill., P. pinaster Ait., P. nigra Arn. and P. pinea L. J. Ecol. 2001, 89, 629-638. [CrossRef]

32. Fernandes, P.M.; Rigolot, E. The fire ecology and management of maritime pine (Pinus pinaster Ait.). For. Ecol. Manag. 2007, 241, 1-13. [CrossRef]

33. Bauer, G.; Speck, T.; Blömer, J.; Bertling, J.; Speck, O. Insulation capability of the bark of trees with different fire adaptation. J. Mater. Sci. 2010, 45, 5950-5959. [CrossRef]

34. Madrigal, J.; Souto-García, J.; Calama, R.; Guijarro, M.; Picos, J.; Hernando, C. Resistance of Pinus pinea L. bark to fire. Int. J. Wildland Fire 2019, 28, 342-353. [CrossRef]

35. Espinosa, J.; Rodríguez de Rivera, O.; Madrigal, J.; Guijarro, M.; Hernando, C. Predicting potential cambium damage and fire resistance in Pinus nigra Arn. ssp. salzmannii. For. Ecol. Manag. 2020, 474, 118372. [CrossRef]

36. Rötzer, T.; Seifert, T.; Gayler, S.; Priesack, E.; Pretzsch, H. Effects of stress and defence allocation on tree growth: Simulation results at the individual and stand level. In Growth and Defence in Plants; Matyssek, R., Schnyder, H., Oßwald, W., Ernst, D., Munch, J.-C., Pretzsch, H., Eds.; Ecological Studies; Springer: Berlin, Germany, 2012; Volume 220, pp. 401-443. 
37. Vanninen, P.; Mäkelä, A. Needle and stem wood production in scots pine (Pinus sylvestris) trees of different age, size and competitive status. Tree Physiol. 2000, 20, 527-533. [CrossRef]

38. Poljanšek, S.; Levanič, T.; Ballian, D.; Jalkanen, R. Tree growth and needle dynamics of P. nigra and P. sylvestris and their response to climate and fire disturbances. Trees 2015, 29, 683-694. [CrossRef]

39. Wyant, J.G.; Laven, R.D.; Omi, P.N. Fire effects on shoot growth characteristics of ponderosa pine in Colorado. Can. J. For. Res. 1983, 13, 620-625. [CrossRef]

40. Chambers, J.L.; Dougherty, P.M.; Hennessey, T.C. Fire: Its effects on growth and physiological processes in conifer forests. In Stress Physiology and Forest Productivity; Springer: Dordrecht, The Netherlands, 1986; pp. 171-189.

41. Villarrubia, C.R.; Chambers, J.L. Fire: Its effects on growth and survival of loblolly pine, Pinus taeda L. Proc. Acad. Sci. 1978, 41, 85-93.

42. Botelho, H.S.; Fernandes, P.; Loureiro, C.; Rego, F. Growth response of maritime pine (Pinus pinaster) trees to high-intensity prescribed fires. In Proceedings of the 3rd International Conference on Forest Fire Research \& 14th Fire and Forest Meteorology Conference ADAI, Luso, Portugal, 16-20 November 1998; pp. 1863-1873.

43. Espinosa, J.; Madrigal, J.; Pando, V.; de la Cruz, A.C.; Guijarro, M.; Hernando, C. The effect of low-intensity prescribed burns in two seasons on litterfall biomass and nutrient content. Int. J. Wildland Fire 2020, 29, 1029-1041. [CrossRef]

44. Madrigal, J.; Fonturbel, T.; de las Heras, J.; Rodríguez y Silva, J.; Ruiz, A.D. Vulnerabilidad Integral de los Sistemas Forestales Frente a Incendios: Implicaciones en las Herramientas de Gestión Forestal "VIS4FIRE". III Taller de Lecciones Aprendidas; UCO-Laboratorio de Incendios Forestales, Ed.; UCO: Córdoba, Spain, 2018; pp. 212-219. ISBN 978-84-09-05314-8.

45. Plaza-Álvarez, P.; Lucas-Borja, M.; Sagra, J.; Moya, D.; Fontúrbel, T.; de las Heras, J. Soil respiration changes after prescribed fires in Spanish black pine (Pinus nigra Arn. ssp. salzmannii) monospecific and mixed forest stands. Forests 2017, 8, 248. [CrossRef]

46. Espinosa, J.; Rodríguez De Rivera, Ó.; Madrigal, J.; Guijarro, M.; Hernando, C. Use of Bayesian modeling to determine the effects of meteorological conditions, prescribed burn season, and tree characteristics on litterfall of Pinus nigra and Pinus pinaster stands. Forests 2020, 11, 1006. [CrossRef]

47. AEMET. Weather Data from Cañizares Station (Cuenca-Spain) 1997-2018; State Meteorological Agency of Spanish Government (AEMET): Madrid, Spain, 2018.

48. Espinosa, J.; Madrigal, J.; De La Cruz, A.C.; Guijarro, M.; Jimenez, E.; Hernando, C. Short-term effects of prescribed burning on litterfall biomass in mixed stands of Pinus nigra and Pinus pinaster and pure stands of Pinus nigra in the Cuenca Mountains (Central-Eastern Spain). Sci. Total Environ. 2018, 618, 941-951. [CrossRef]

49. Vega, J.A. Efectos del Fuego Prescrito Sobre el Suelo en Pinares de Pinus pinaster Ait. Ph.D. Thesis, Universidad Politécnica de Madrid, Madrid, Spain, 2001; 417p.

50. Graves, S.J.; Rifai, S.W.; Putz, F.E. Outer bark thickness decreases more with height on stems of fire-resistant than fire-sensitive Floridian oaks (Quercus spp.; Fagaceae). Am. J. Bot. 2014, 101, 2183-2188. [CrossRef]

51. Martinson, E.J.; Omi, P.N. Fuel Treatments and Fire Severity: A Meta-Analysis; Research Paper; RMRS-RP-103WWW; Department of Agriculture, Forest Service: Fort Collins, CO, USA, 2013.

52. Espinosa, J.; Palheiro, P.; Loureiro, C.; Ascoli, D.; Esposito, A.; Fernandes, P.M. Fire-severity mitigation by prescribed burning assessed from fire-treatment encounters in maritime pine stands. Can. J. For. Res. 2019, 49, 205-211. [CrossRef]

53. Byram, G.M. Combustion of forest fuels. In Forest Fire: Control and Use; McGraw-Hill: New York, NY, USA, 1959 ; pp. 61-89.

54. Ukonmaanaho, L.; Pitman, R.; Bastrup-Birk, A.; Breda, N.; Rautio, P. Part XIII: Sampling and Analysis of Litterfall. In Manual on Methods and Criteria for Harmonized Sampling, Assessment, Monitoring and Analysis of the Effects of Air Pollution on Forests; UNECE ICP Forests Programme Coordinating Centre, Ed.; Thünen Institute for Forests Ecosystems: Eberswalde, Germany, 2016; 15p.

55. Stokes, M.A.; Smiley, T.L. An Introduction to Tree-Ring Dating; University of Chicago Press: Chicago, IL, USA, 1968.

56. Rinn, F. TSAP-Win Professional, Time Series Analysis and Presentation for Dendrochronology and Related Applications; Version 0.3; Rinntech: Heidelberg, Germany, 2003; Quick reference.

57. Martin-Benito, D.; Anchukaitis, K.; Evans, M.; Beeckman, H.; del Rio, M.; Cañellas, I. Effects of drought on xylem anatomy and water use efficiency of two co-occurring pine species. Forests 2017, 8, 332. [CrossRef]

58. Holmes, R.L. Computer-assisted quality control in treering dating and measurement. Tree Ring Bull 1983, 43, 69-75.

59. Biondi, F. Comparing tree-ring chronologies and repeated timber inventories as forest monitoring tools. Ecol. Appl. 1999, 9, 216-227. [CrossRef]

60. Varner, J.M.; Putz, F.E.; O’Brien, J.J.; Hiers, J.K.; Mitchell, R.J.; Gordon, D.R. Post-fire tree stress and growth following smoldering duff fires. For. Ecol. Manag. 2009, 258, 2467-2474. [CrossRef]

61. Sala, A.; Peters, G.; McIntyre, L.; Harrington, M. Physiological responses of ponderosa pine in western Montana to thinning, prescribed fire and burning season. Tree Physiol. 2005, 25, 339-348. [CrossRef] [PubMed]

62. Bottero, A.; D'Amato, A.W.; Palik, B.J.; Kern, C.C.; Bradford, J.B.; Scherer, S.S. Influence of repeated prescribed fire on tree growth and mortality in Pinus resinosa forests, northern Minnesota. For. Sci. 2017, 63, 94-100. [CrossRef]

63. Seifert, T.; Meincken, M.; Odhiambo, B.O. The effect of surface fire on tree ring growth of Pinus radiata trees. Ann. For. Sci. 2017, 74, 34. [CrossRef]

64. Sutherland, E.K.; Covington, W.W.; Andariese, S. A model of ponderosa pine growth response to prescribed burning. For. Ecol. Manag. 1991, 44, 161-173. [CrossRef] 
65. Peterson, D.L.; Arbaugh, M.J.; Pollock, G.H.; Robinson, L.J. Postfire growth of Pseudotsuga menziesii and Pinus contorta in the Northern Rocky Mountains, USA. Int. J. Wildland Fire 1991, 1, 63-71. [CrossRef]

66. Ford, C.R.; Emily, S.M.; Gordon, A.F. Long-term effects of fire and fire-return interval on population structure and growth of longleaf pine (Pinus palustris). Can. J. For. Res. 2010, 40, 1410-1420. [CrossRef]

67. Debano, L.F.; Neary, D.G.; Folliot, P.F. Fire Effects on Ecosystems; Wiley: New York, NY, USA, 1998.

68. DeLuca, T.H.; Zouhar, K.L. Effects of selection harvest and prescribed fire on the soil nitrogen status of ponderosa pine forests. For. Ecol. Manag. 2000, 138, 263-271. [CrossRef]

69. Alfaro-Sánchez, R.; Camarero, J.J.; Sánchez-Salguero, R.; Trouet, V.; Heras, J.D.L. How do Droughts and Wildfires Alter Seasonal Radial Growth in Mediterranean Aleppo Pine Forests? Tree-Ring Res. 2018, 74, 1-14. [CrossRef]

70. Busse, M.D.; Simon, S.A.; Riegel, G.M. Tree-growth and understory responses to low-severity prescribed burning in thinned Pinus ponderosa forests of central Oregon. For. Sci. 2000, 46, 258-268.

71. Blanck, Y.L.; Rolstad, J.; Storaunet, K.O. Low-to moderate-severity historical fires promoted high tree growth in a boreal Scots pine forest of Norway. Scand. J. For. Res. 2013, 28, 126-135. [CrossRef]

72. Felton, A.; Lindbladh, M.; Brunet, J.; Fritz, Ö. Replacing coniferous monocultures with mixed-species production stands: An assessment of the potential benefits for forest biodiversity in northern Europe. For. Ecol. Manag. 2010, 260, 939-947. [CrossRef]

73. Loreau, M. Biodiversity and Ecosystem Functioning: Current Knowledge and Future Challenges. Science 2001, 294, 804-808. [CrossRef] [PubMed]

74. Jactel, H.; Nicoll, B.C.; Branco, M.; González-Olabarría, J.R.; Grodzki, W.; Långström, B.; Moreira, F.; Netherer, S.; Orazio, C.; Piou, D.; et al. The Influences of forest stand management on biotic and abiotic risks of damage. Ann. For. Sci. 2009, 66, 701. [CrossRef]

75. Linares, J.C.; Camarero, J.J.; Carreira, J.A. Interacting effects of changes in climate and forest cover on mortality and growth of the southernmost European fir forests. Glob. Ecol. Biogeogr. 2009, 18, 485-497. [CrossRef]

76. De Luis, M.; Cufar, K.; Di Filippo, A.; Novak, K.; Papadopoulos, A.; Piovesan, G.; Rathgeber, C.B.K.; Raventos, J.; Saz, M.A.; Smith, K.T. Plasticity in dendroclimatic response across the distribution range of Aleppo Pine (Pinus halepensis). PLoS ONE 2013, 8, e83550. [CrossRef]

77. Martin-Benito, D.; Kint, V.; Del Rio, M.; Muys, B.; Cañellas, I. Growth responses of West-Mediterranean Pinus nigra to climate change are modulated by competition and productivity: Past trends and future perspectives. For. Ecol. Manag. 2011, 262, 1030-1040. [CrossRef]

78. Swezy, D.M.; Agee, J.K. Prescribed fire effects on fine-root and tree mortality in old-growth ponderosa pine. Can. J. For. Res. 1991, 21, 626-634. [CrossRef]

79. Harrington, M. Predicting Pinus ponderosa mortality from dormant season and growing season fire injury. Int. J. Wildland Fire 1993, 3, 65-72. [CrossRef]

80. Odhiambo, B.; Meincken, M.; Seifert, T. The protective role of bark against fire damage: A comparative study on selected introduced and indigenous tree species in the Western Cape, South Africa. Trees 2014, 28, 555-565. [CrossRef]

81. Wesolowski, A.; Adams, M.A.; Pfautsch, S. Insulation capacity of three bark types of temperate Eucalyptus species. For. Ecol. Manag. 2014, 313, 224-232. [CrossRef]

82. Rozas, V.; Gonzalo, P.D.L.; Ignacio, G.G.; Jose, R.A. Contrasting effects of wildfire and climate on radial growth of Pinus canariensis on windward and leeward slopes on Tenerife, Canary Islands. Trees 2001, 25, 895-905. [CrossRef]

83. Certini, G. Effects of fire on properties of forest soils: A review. Oecologia 2005, 143, 1-10. [CrossRef] [PubMed]

84. Retzlaff, M.; Keane, R.; Affleck, D.; Hood, S. Growth response of whitebark pine (Pinus albicaulis Engelm) regeneration to thinning and prescribed burn treatments. Forests 2018, 9, 311. [CrossRef]

85. De Micco, V.; Zalloni, E.; Balzano, A.; Battipaglia, G. Fire influence on Pinus halepensis: Wood responses close and far from the scars. IAWA J. 2013, 34, 446-458. [CrossRef]

86. Gordon, C.; Larson, P.R. Seasonal course of photosynthesis, respiration, and distribution of $14 \mathrm{C}$ in young Pinus resinosa trees as related to wood formation. Plant Physiol. 1968, 43, 1617-1624. [CrossRef]

87. Waring, R.H.; Schlesinger, W.H. Forest Ecosystems: Concepts and Management; Academic Press: New York, NY, USA, 1985; 390p.

88. Oliver, C.D.; Larson, B.C. Forest Stand Dynamics; McGraw-Hill: New York, NY, USA, 1966; 520p. 